\title{
DOES THE TIMING OF WORK INTEGRATED LEARNING AFFECT GRADUATE EMPLOYABILITY OUTCOMES?
}

\section{E. C. Garwe}

Zimbabwe Council for Higher Education

Harare, Zimbabwe

e-mail: garweec@gmail.com / https://orcid.org/0000-0002-6111-8622

\section{ABSTRACT}

Employability is a critical quality measure of student lifelong success that goes beyond grade achievement and often guides students' choice of university and profession. Whilst studies highlighting the importance of work-integrated learning (WIL) in improving employability abound, there is a dearth of knowledge on the efficacy of timing of WIL as a variable in improving employability. The longitudinal study, carried out in a 3-year annual questionnaire-based survey, examines the effect of timing of WIL on employability status when student performance is held constant. Graduates possessing the same performance level (academic degree class 2.1) showed different levels of economic-engagement achievements depending on whether they engaged in WIL prior to their studies (Group A), throughout the learning period (Group B) or for nine months during the third year (Group $C$ ) of their studies. Although the findings revealed differences between timing of WIL and the nature of work engagement, all the graduates endorsed the critical role of WIL in building work-related competencies and thus improving employability. The findings are useful in promoting the necessary diversity in WIL curriculum design to facilitate quality and inclusive higher education.

Keywords: student success, employability, work-integrated learning, longitudinal study, competencies

\section{INTRODUCTION}

The role of higher education institutions (HEIs) as hotspots for innovation, research and knowledgeability (highly-skilled manpower development), is well acknowledged (e.g. Hoang 2018). The human capital theory (Schultz 1961) attributes higher industrial productivity and economic growth primarily to the value addition to labour/employees brought about by higher education's ability to develop knowledge, skills, professionalism, enlightenment and other competencies required at the workplace (Bridgstock 2009). Higher education begets benefits at the individual, institutional, national, regional and global levels. These include student success as well as enriching the reputational and economic competitiveness of the institution, the nation and the society (Hagel et al. 2014). HEIs achieve this feat by nurturing high end competencies in graduates to equip them to respond to the ever changing socio-economic, technological, 
cultural and global environment for lifelong success. In addition, Wright, Davis and Bucolo (2013) expects quality graduates to be groomed in such a way that they are knowledgeable, skilled, professional and adaptable enough to fit into a broad range of business contexts inclusive of self-employment, small and medium enterprises and micro-enterprises.

Higher education has undergone changes during the past two decades due to technological advances, pressures from the workplace and the society in general (Wessels and Jacobs 2010). Traditionally, the higher education curriculum was generally targeted towards developing graduates with a discipline knowledge-skill base who could easily adapt to the work environment through additional in-service training (Weddle 2010). Over and above disciplinary knowledge and skills as testified by academic qualifications, the contemporary business and industry environment now demands well rounded and work-ready graduates who can hit the ground running with minimal additional training investment (Peach and Gamble 2011). Work experience has thus emerged as a must-have and a significant precedent for employability in order to develop the required labour market awareness and skills. Accordingly, the higher education curriculum has now shifted emphasis from learning "for work" to learning "at work" and learning "through work" in order to position graduates at the nexus of rapidly transforming higher education and employment sectors (Wright et al. 2013).

Employability has a multiplicity of definitions, for the purposes of this article it is defined as that which an HEI does in response to enhancing its curriculum, pedagogy, brokerage to create social capital networks and workplace habits that would garner benefits for the students (Okafor 2015). Employability goes beyond the acquisition of jobs or occupations by graduate securing a place in the labour market but it is also about the student being able to apply that what they have learnt and acquired. Employability is a critical quality measure of student lifelong success that goes beyond grade achievement and often guides students' choice of university and profession (Bringle, Hatcher and Richard 2010; Morley 2002; Støren and Aamodt 2010). Employability skills are generally categorized into those specific to the discipline and those that are generic/transferable. It therefore requires a holistic approach to integrating discipline-related theoretical concepts and industry experience to produce employable graduates (Wolff and Booth 2018). World-over, there is a clarion call for institutions, nations and regions to position employability strategically for student lifelong socio-economic success (Divan and McBurney 2016; Kinash et al. 2016; Suleman 2018). In response, governments and institutions have "moved work-integrated learning (WIL) from the periphery to the centre of their curricula" (Nguyen 2019) so as to make graduates work-ready (Artess, Mellors-Bourne and Hooley 2017; Clarke 2017; Cooper, Orrell and Bowden 2010; Jackson 2013; Wilton 2012). 


\section{THE CONCEPT OF WORK INTEGRATED LEARNING}

Work-integrated learning refers to the practical part of the curriculum where students are exposed to authentic/actual workplaces (as opposed to simulated work places) wherein learning occurs through active participation in work activities and programmes orientated around current and /or future careers (Comyn and Brewer 2018; Hills et al. 2003; Rambe 2018; Roopnarain and Akoobhai 2014; Webb and Hayes 2008). Literature uses many different terminologies to denote the formal mutual arrangement between business and higher education that is grounded in experiential learning (McKune 2013). These terms range from work-based/related learning; clinical/field education, cooperative learning (Wessels 2014), industrial attachment/placement (Leong 2004), practical training/internship (Rodzalan and Saat 2012). It goes without saying that "students who have broad and deep conceptions of their future professional work transit into the world of work with relative ease" (Sin, Reid and Jones 2012, 324). Several studies affirm WIL as having benefits in:

- combining theory with practice (McKinnon 2013) resulting in enhanced technical expertise (Dall'Alba 2004);

- strengthening students' understanding of the culture, expectations and requirements of the working environment (Jackson 2016);

- $\quad$ creating professional identity (Trede 2012);

- establishing relevant industry/occupational networks (Martin and Hughes 2009); and

- developing generic/transferable/non-technical skills (Ferns, Campbell and Zegwaard 2014; Hoeckel 2014; Smith, Ferns and Russell 2014).

These generic skills include: confidence, courage, innovation capacity, leadership and decisionmaking skills that cannot be attainable through exclusive exposure to classroom learning (D'Abate, Youndt and Wenzel 2009); Kyndt and Baert 2013; Rampersad and Zivotic-Kukolj 2018).

It is clear from the foregoing that employability is a function of both performance and performance character of graduates. Performance describes the graduate outcomes in terms of the competencies (knowledge and skills) as reflected by the award or grade achievement. Performance character denotes those characteristics or dispositions required to prime one's thoughts, behaviours and actions to achieve one's personal best in any endevour (Park et al. 2016; Seider et al. 2013) and are usually acquired through WIL. 
WIL if flexible and applicable to different contexts and disciplines. For example, in the United State of America WIL is embedded into formal on-campus teaching and learning. Hanna et. al. (2011) describes WIL in the context of the United Kingdom to occur during the third year of studied allowing students an initial two years of learning before WIL and a final year after WIL. The Australian context, according to Dickson and Kaider (2012) is flexible depending on business and community requirements.

The different times WIL is structured during the course of an undergraduate degree programme and the efficacy of these times on graduate employability require further enquiry. However, despite the extant literature on the challenges and importance of WIL (Mounce, Mauldin and Braun 2004) there is a dearth of knowledge on the effectiveness of timing of WIL in improving employability. This becomes particularly important in in addressing issues of quality, harmonisation and diversity of higher education within national or regional contexts. Zimbabwe provides an example of a country that is currently revolutionising its higher education curriculum and is used as a case country in this study aimed at investigating on the views of graduates on the effectiveness of timing of WIL in improving employability.

\section{THE PROBLEM}

Zimbabwe is undertaking an ambitious project on harmonising curriculum through the introduction of minimum bodies of knowledge and skills (MBKs) to be adopted by all universities. This exercise is part of a broader harmonization agenda aimed at enhancing quality through transferability of credits and recognition of university qualifications. In light of the foregoing discussion on the disparities between the timing of WIL, and the assertion by Billet (2011) that variability in WIL begets distinct outcomes, it becomes critical to be guided by empirical evidence. However, despite several studies being undertaken worldwide and in Zimbabwe in particular (refer to a synthesis of these studies by Muchemwa 2018) on WIL, most of these are largely cross-sectional, descriptive, repetitive and uncritical regarding the efficacy of the timing of WIL on employability.

This study uses agriculture as an example of those degree programmes whose curriculum is structured differently with WIL coming before, throughout or during the penultimate year of training. The author is knowledgeable about agricultural training and has intricate networks in agricultural training institutions, agri-business and employment sector and agriculture practice in general. This became critical in identifying and following up participants for the study to increase response rates. The study sought to answer the following specific questions:

(i) Do graduates that performed WIL at different times during the course of their studies have 
the similar employability outcomes.

(ii) Are the graduates satisfied with the timing of their WIL and why?

(iii) What lessons can be gleaned from the study for wider use?

\section{METHODOLOGY AND STUDY CONTEXT}

\section{WIL in Zimbabwe}

The origins of WIL in Zimbabwe can be traced to the innovative Zimbabwe Integrated Teacher Education Course (ZINTEC), a unique four-year post-independence programme introduced in 1983 to train primary school teachers (Phuthi 2012). The ZINTEC "sandwich" programme was intended to integrate theory, professional and on-the-job training/learning to produce high quality teachers at the same time establishing a vibrant link between higher education and employment (Chivore 1994). Apart from the face-to-face courses undertaken by students during the residential learning periods at college at the beginning and at the end of the course, some pedagogical courses were accomplished via distance learning. Students received academic and professional guidance, supervision and assessment from lecturers and senior teachers respectively.

In the mid-1980s the Bulawayo Polytechnic and the Harare Polytechnic adopted the WIL concept as part of their compulsory teaching and learning pedagogy for the newly launched Bachelor of Technology in Management degree programme. This was the first time in the history of Zimbabwe for a non-university higher education institution to offer degree programmes resulting in the programme being temporarily relocated to the University of Zimbabwe (which was offering a similar programme but without compulsory one-year WIL) and eventually discontinued.

The first university to adopt WIL, dubbed "industrial attachment," was the National University of Science and Technology (NUST) which opened its doors in 1991 as the second university to be established in Zimbabwe after the University of Zimbabwe. The undergraduate degree programmes were structured in such a way that NUST students spent the penultimate year of their studies in industry (NUST 2003). The additional universities (both public and private) that were established henceforth adopted WIL as a best practice varying only the terminology to also include work-related learning, student attachment, internship and workbased placement. The University of Zimbabwe introduced WIL for all programmes as from 2002, effectively adding a full additional year to the duration of their programmes.

Over the years universities in Zimbabwe have diversified their teaching and learning modes of delivery from exclusively conventional face-to-face to also include more flexible non- 
residency approaches featuring online and distance learning (ODL). Furthermore, universities expanded the conventional face-to-face model to include targeted programmes wherein students do not have to travel to the university campus but are taught within their work or residential premises, a concept referred to as "moving the university to the people" (Garwe and Thondhlana 2019, 8). Furthermore, weekend, evening and the block release models were introduced as variations and blends of the conventional and ODL methods. Blocks are characterised by a blend of face-to-face and ODL delivery was also introduced with students attending "blocks" of varying durations depending on their availability. The "inclusive" and innovative "learner-centred" models were aimed at improving access and customer satisfaction whilst keeping an eye on quality. Block release, weekend, evening and ODL models are generally subscribed to by the working class and other socially, economically or politically engaged students seeking to improve their competencies.

The new modes of teaching and learning discussed above resulted in an adaptation of WIL format and duration. There is however, no explicit policy or guidelines in Zimbabwe on the format and duration of WRL. Some universities exempt students working in areas related to their study programme from WIL effectively reducing the duration of their studies by one year. This makes such universities attractive to adult learners thereby highlighting the importance of WIL in blurring the boundaries between higher education and business/industry. Some university programmes are specifically targeted at people who work in particular field and hence are designed in such a way that WIL is done throughout the duration of the entire programme. The implication of this is that if the mode of study is held constant, students studying similar programmes might undergo WIL before they commence their studies (as in the case of exemptions), during the penultimate year of study or throughout the study period. This raises a concern on whether the timing of WIL can have effect on graduate employability outcomes.

Agriculture degree programmes have been flagged in the literature particularly from subSaharan Africa as lacking in generic skills that can benefit from WIL and improved employability. In a study covering employers from Ethiopia, Kenya, Malawi, Mozambique, Rwanda and Tanzania, Blackie, Mutema and Ward (2009) found deficiencies in written and communication skills of agricultural graduates. Similar studies in Kenya, Uganda, Mozambique, Nigeria, and South Africa found employers to be dissatisfied with graduates' poor communication, leadership, interpersonal skills and work experience (Breazeale et al. 2004; Ouraich et al. 2017). Recently, there has been a growing sense of urgency to promote agripreneurship in agriculture graduates to spur technological and economic growth (Chaurasiya et al. 2016). WIL affords students the much needed understanding of the intricacies 
of enterprise development and management beyond what is taught in class.

\section{Participants, instruments and procedures}

The longitudinal study compared the graduate economic-engagement outcomes (employability status) of agricultural graduates from three different universities who had engaged in WIL at three different times: prior to their studies (Group A); throughout the learning period (Group B); and for nine months during the third year (Group C) of their studies. Graduate performance level (academic degree class) was held constant by recruiting only those who had graduated with upper second (2.1) degree classification as participants of the study. This was intended to remove the graduate performance and the university variable so as to measure the variability resulting from the three different timings of WIL on employability status. The researcher however notes potential limitation in the quality of the different WIL experiences among the graduates. Such a limitation is to some extent overshadowed by the fact that even if it existed, its effects were flattened by the fact that the graduates scored similar grade achievements which was the result of all their efforts and exposures before the final assessment.

Data was collected at three different time periods between September 2015 and December 2018. Although students were voluntarily recruited into the study on their graduation day, the first, second and third sets of employability-related data were collected at the completion of one, two and three years' post-graduation respectively (Time 1, 2, and 3). Participants were apprised of rationale, confidentiality and procedure of the study on their graduation day. As advised by Salkind (2012), they were made aware that through participating in the study, no harm either psychological or physical, would befall them. Purposive sampling was used to select appropriate (degree class 2.1) graduates who showed their willingness to participate by signing ethical informed consent forms and submitting their personal information including sex and contact details. Their email addresses were used to send calendar-enabled electronic selfadministered graduate employability status questionnaires (GESQs) which they were requested to complete and send to the email addresses provided prompted at Time 1,2 and 3. The GESQs was designed to seek quantitative (descriptive statistics) and qualitative information on graduates' perception on how the timing of their WIL influenced their employability status. This qualitative information added depth and direction on best practices regarding the impact of timing of WIL on employability of agriculture graduates.

The GESQs classified employability status into six categories: full-time (permanent or fixed term contract) formal employment; part-time (causal / temporary / seasonal) formal employment; self-employment; postgraduate student; enterprise start-up and unemployment. Formal employment was defined as engagement in agriculture-related remunerated work within businesses/enterprises registered with the state, private sector or non-governmental 
organisations. Examples of formal employers are: universities, colleges, schools and other training and research institutions; agro-industries (e.g. fertiliser, pesticides, chemicals, processing, marketing); banking, finance and insurance; game reserves and farms. Selfemployment was defined as freelance economic activity derived by an individual using competencies gained during their agriculture training to generate own income. This was a distinct category from enterprise creation where the individual may still use their professional knowledge but register a formal company that pays taxes and employs other workers. Those who were engaged in postgraduate studies on a part-time basis would still belong to any of the other groups and hence they were not put in a specific category of their own.

Thirty graduates were purposively (depending on the required performance level) selected from graduates with a "2.1" grade achievement from each of the three universities representing the three different WIL timing requirements resulting in a sample of 90 graduates. Besides the calendar prompts, group-email reminders were sent to participants a week before and after Time 1,2 and 3 in order to increase the response rate. A total of 181 GESQs were returned (representing a 67\% response rate), of these, 60, 66 and 55 were completed for Time 1, 2, and 3 respectively. When the three data sets were pooled and aggregated against each participant, it emerged that of the 90 participants in the study, 30 had complete data sets having completed their GESQs at Time 1, 2, and 3; 38 completed GESQs twice; 18 completed GESQs once and 5 absconded. The fact that some participants only provided information at Time 2 or 3 made it difficult to obtain information on exactly how long after graduation each of them started economic activities. This was the justification for a longitudinal study which has the ability to capture information of a transient nature over time. Employability studies fall into this category of studies.

Overall, 150 GESQs (representing a 55.5\% response rate) were used for analysis having discarded 31 incomplete questionnaires. Of the usable GESQs, 32 per cent and 68 per cent from female and male participants respectively, against ratio of 40 per cent female to 60 per cent male from the original sample. It is the author's conviction that a 55.5 per cent usable GESQs response rate compares well with related studies using similar methodologies for example the 20 per cent, 41 per cent and 54 per cent response rates reported by Prince (2005), Maher (2004) and Shah, Pel and Brooke (2004), respectively.

The higher (67\%) overall response rate's explanation is threefold: First, the participants were made fully aware of the GESQ rationale and procedure at the recruitment stage. Second, collecting data electronically through email is not affected by distance or geographical boundaries characteristic of studies of this nature, even those in the Diaspora could be reached easily. Lastly, in instances where email accounts recorded at recruitment changed, there was an instant "delivery failure" return. As explained before, the researcher's networks were leveraged 
on to help in identifying the whereabouts and new emails of participants. Some participants voluntarily provided information on changes in their contacts to the researcher. When viewed from a different angle, this attachment between the researcher and participants presents a limitation to the study deriving from participants who might desire to present themselves in good light. Literature cautions against the use of self-reported data which can be prone to biases of self-esteem (Gonyea 2005) and social desirability (Archambault 2011) as compounded by lack of researcher detachment from participants. Notwithstanding these limitations, information of employability statuses is quite difficult to fake since it can easily be cross-checked within a profession like agriculture.

\section{FINDINGS AND DISCUSSION}

The study set out to ascertain the effect of three different timings of WIL on graduate employability with respect to agricultural graduates. The data showed that the different groups had different ages as shown in Table 1. This can be explained by the fact that Group A graduates largely comprise those students who after completing their secondary education, go through the diploma route at agricultural training colleges, get into internship or employment before enrolling for university studies. They therefore tend to be a bit older than Group $\mathrm{C}$ graduates who go to university straight from their Advanced level studies and are exposed to WIL during the penultimate year of their studies. Group B graduates enter into full time employment before they engage in university studies. They remain employed throughout their studies which they undertake by block release or though other part-time modes. Since their agriculture degree studies are related to their work, they are considered to be on WIL throughout their study period. This explains why the average age of Group B graduates was higher than the other two groups.

Table 1: Average age for Groups 1-3

\begin{tabular}{|l|c|c|c|}
\hline & Group A & Group B & Group C \\
\hline Average age & 28 & 35 & 24 \\
\hline
\end{tabular}

Figure 1 shows the employability outcomes from the GESQs according to the timing of WIL namely: prior to their studies (Group A); throughout the learning period (Group B); and for nine months during the third year (Group C) of their studies. The bulk of Group A graduates (69\%) were in formal employment either on a full time $(46 \%)$ or part time $(23 \%)$ basis. A significant component $(27 \%)$ were self-employed whilst 4 per cent of were postgraduate students. No members of this group had either set up an enterprise or were unemployed.

For Group B graduates, (60\%) were in formal employment either on a full time $(53 \%)$ or part time (7\%) basis. Those self-employed comprised 17 per cent of the group whilst 13 per 
cent were postgraduate students. It was interesting to note that 21 per cent of graduates had started enterprises. No members of this group were unemployed.

The majority of Group C graduates (79\%) were in formal employment either on a full time $(69 \%)$ or part time $(10 \%)$ basis. A significant component $(21 \%)$ were postgraduate students. No members of this group were either self-employed or unemployed.

Figure 2 shows a holistic snapshot of the employability outcomes for Groups A-C revealing that: no member of any of the groups was unemployed; only group B had members who had started enterprises; and that a majority of members from all groups was in full time formal employment. Figure 3 shows the percentage of graduates who were satisfied with the timing of their WIL. Group C students were highly satisfied with the timing of their WIL.

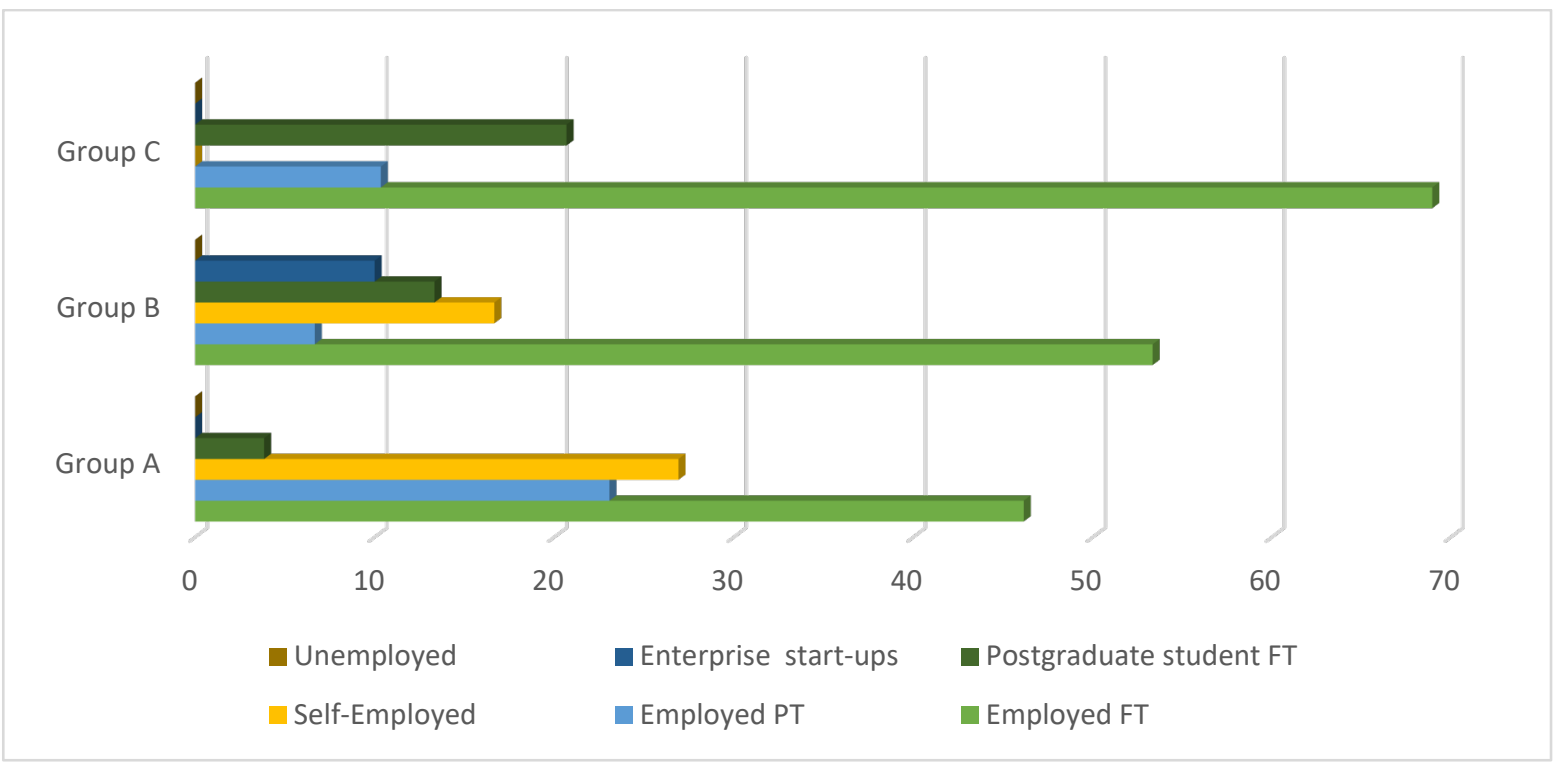

Figure 1: Employability outcomes according to the timing of WIL for Groups A-C

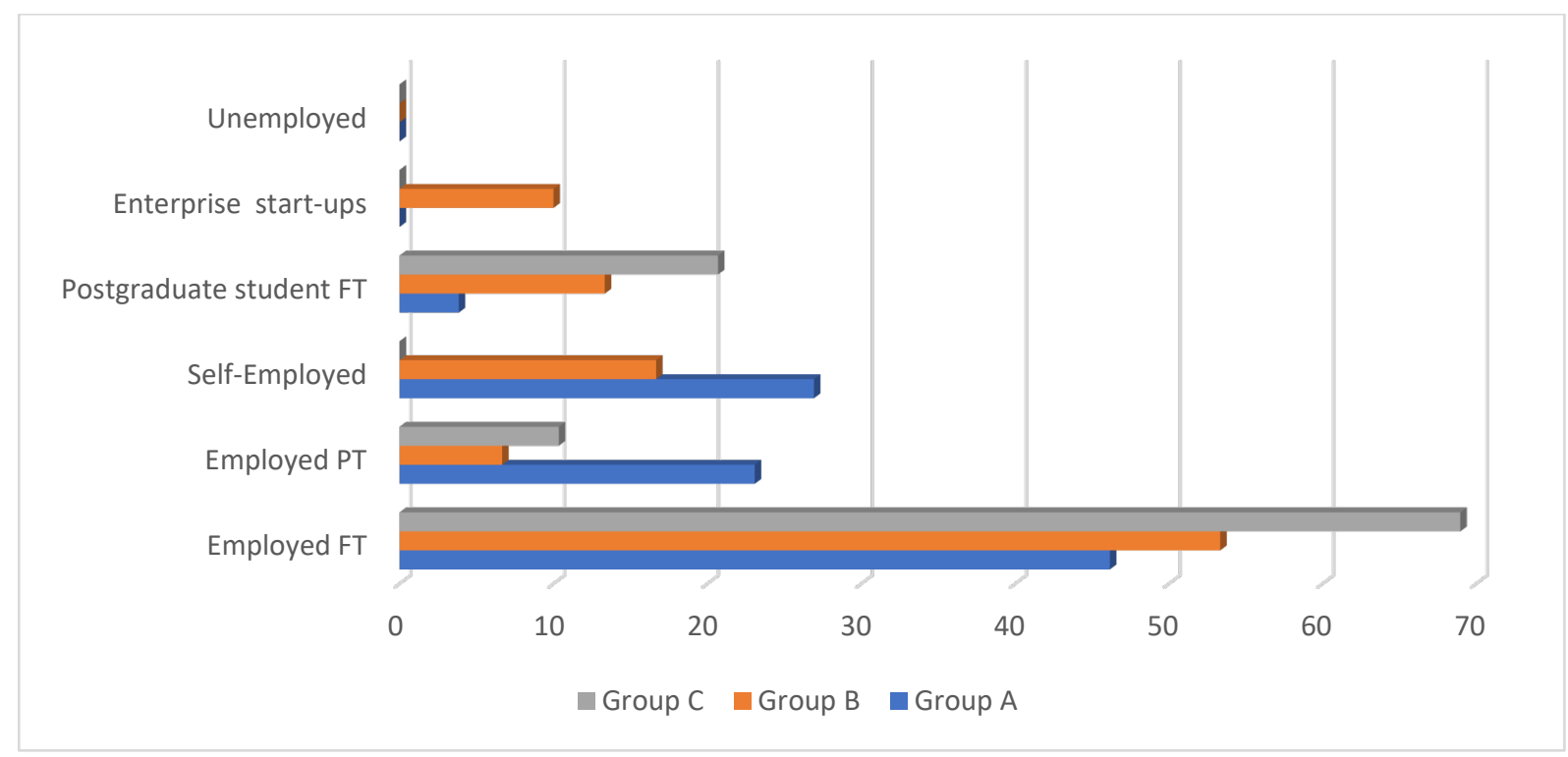

Figure 2: Holistic snapshot of the employability outcomes for Groups A-C 


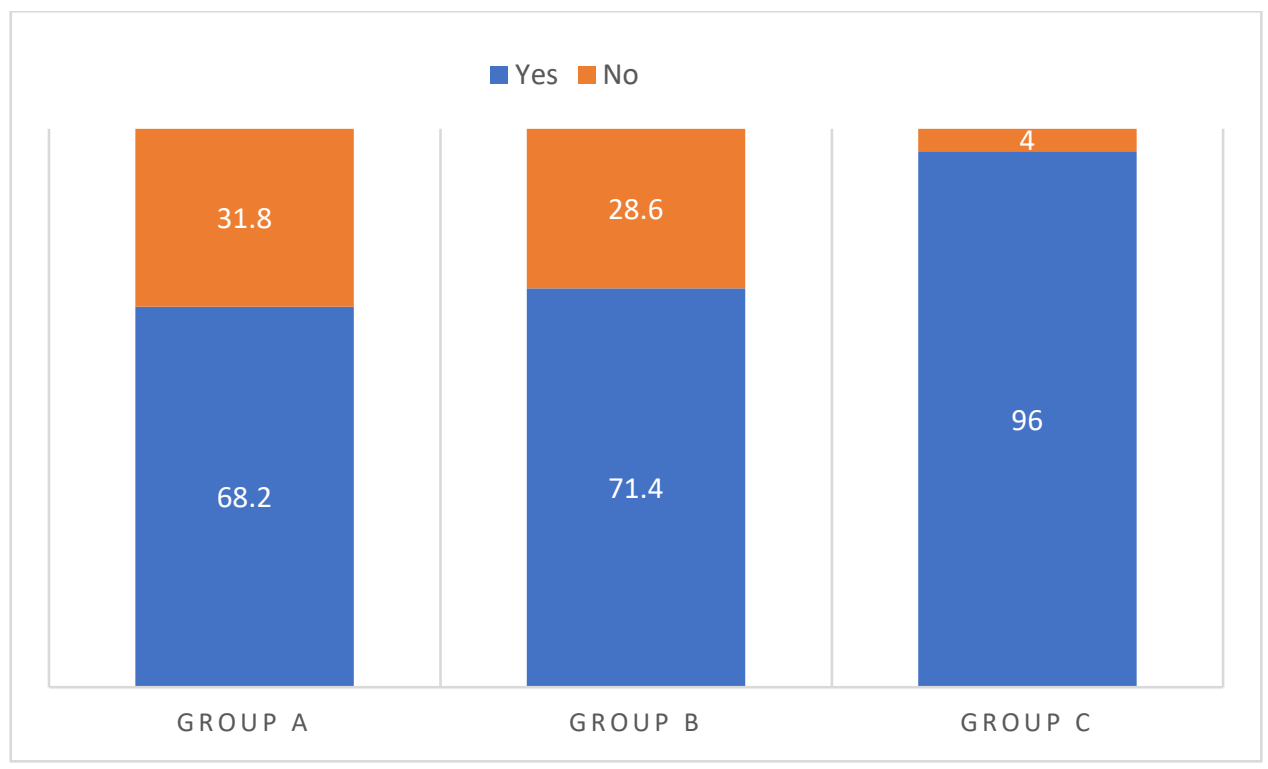

Figure 3: Holistic snapshot of the employability outcomes for Groups A-C

Table 2: Reasons why graduates were satisfied with the timing of their WIL

\begin{tabular}{|l|c|c|c|}
\hline \multicolumn{1}{|c|}{ Reasons } & Group A & Group B & Group C \\
\hline $\begin{array}{l}\text { WIL empowered me with work content, methodological, learning and } \\
\text { social competencies }\end{array}$ & $\mathrm{xx}$ & $\mathrm{x}$ & $\mathrm{xxx}$ \\
\hline $\begin{array}{l}\text { WIL developed in me the right attitudes and values to increase } \\
\text { quality of work output }\end{array}$ & $\mathrm{xxx}$ & $\mathrm{xxx}$ \\
\hline $\begin{array}{l}\text { Employers want tried and tested (with work experience) adequately } \\
\text { trained employees who need minimum supervision }\end{array}$ & & $\mathrm{xxx}$ \\
\hline $\begin{array}{l}\text { I was hired by their firms of attachment due to good performance } \\
\text { character }\end{array}$ & & $\mathrm{xxx}$ \\
\hline I was able to apply theory into practice on a day to day basis & $\mathrm{xxx}$ & $\mathrm{xxx}$ & $\mathrm{xxx}$ \\
\hline $\begin{array}{l}\text { I knew exactly which areas I needed to acquire more theoretical } \\
\text { knowledge }\end{array}$ & $\mathrm{xxx}$ & $\mathrm{x}$ & $\mathrm{x}$ \\
\hline $\begin{array}{l}\text { I developed entrepreneurial skills that empowered me to work } \\
\text { independently }\end{array}$ & $\mathrm{xxx}$ & $\mathrm{xxx}$ & $\mathrm{xx}$ \\
\hline I was able to get relevant real time work-related guidance & $\mathrm{xxx}$ & $\mathrm{xxx}$ & $\mathrm{xxx}$ \\
\hline WIL developed my communication skills & $\mathrm{x}$ & $\mathrm{xx}$ & $\mathrm{xxx}$ \\
\hline WIL enabled me to situate learning practically & & & \\
\hline $\begin{array}{l}\text { WIL timing made me aware that I needed to study further in order to } \\
\text { reach the right job level }\end{array}$ & & & \\
\hline
\end{tabular}

Key: "x," "xx" and "xxx" designations denote the increasing importance (frequency) of the reason i.e. "41-60\%," "61-80\%", "81-100\%"

It can be seen from Table 2 that when WIL is undertaken before undergraduate training (Group A), the following reasons are extremely important (as denoted by the frequency of response):

a) "WIL developed in me the right attitudes and values to increase quality of work output. A participant had this to say 'My levels of confidence and courage increased tremendously during my attachment. I used to dislike teamwork at university because I did not like other students to copy my work. During my industrial attachment, I learnt the importance of teamwork in improving the quality of work outputs. I got the courage and confidence to apply for a job after graduation and I succeeded!'” 
Zegwaard and McCurdy (2014) also found similar confidence-building benefits of WIL.

b) "I knew exactly which areas I needed to acquire more theoretical knowledge."

c) "I developed entrepreneurial skills that empowered me to work independently."

d) "WIL enabled me to situate learning practically. One of the participants revealed that, 'During my attachment I developed a lot of practical knowledge. However since I was limited on the science part of agriculture, I developed a keen interest in acquiring more academic knowledge. The network of colleagues in industry helped me get through my studies because I always reverted back to the practise to apply knowledge."”

This finding resonates with the assertion by Ferkins (2002) that WIL results in connections that increase employability of graduates.

When WIL is undertaken concurrently throughout the undergraduate training period (Group B) the following reasons are extremely important (as denoted by the frequency it was mentioned):
a) "I was able to apply theory into practice on a day to day basis."
b) "I knew exactly which areas I needed to acquire more theoretical knowledge."
c) "I was able to get relevant real time work-related guidance."
d) "WIL developed my communication skills."
e) "WIL enabled me to situate learning practically."

The graduates who undertook WIL during the penultimate year of their studies (Group C) the following reasons were identified to be extremely important:
a) "WIL empowered me with work, methodological, learning and social competencies."
b) "WIL developed in me the right attitudes and values to increase quality of work output."
c) "Employers want tried and tested (with work experience) adequately trained employees who need minimum supervision."
d) "I was hired by their firms of attachment due to good performance character."
e) "I knew exactly which areas I needed to acquire more theoretical knowledge."
f) "WIL enabled me to situate learning practically."
g) "WIL timing made me aware that I needed to study further in order to reach the right job level."

Two reasons that were cited to be extremely important by all the three groups. These are: a) I knew exactly which areas I needed to acquire more theoretical knowledge and b) WIL enabled me to situate learning practically. As one participant averred "The experience that I acquired from industrial attachment taught me how to learn and reflect on theoretical knowledge."

The findings clearly show that whatever the timing of WIL, it always brings the benefits 
of connecting theory to practice and to improve employability. Dressler and Keeling, (2011) reported similar personal, academic and employability benefits allowing graduates the opportunity and ticket to enter labour markets (Valadkhani, Worthington and Houlbrook 2001) because of their practical analytical and problem solving skills (Crebert et al. 2004; Fleming and Eames 2005; Freudenberg, Brimble and Cameron 2011).

The finding that 21 per cent of Group B graduates who undertook WIL throughout the study period had developed enterprises within 3 years post-graduation and was the only group that did so, may point to the importance of sustained exposure to both theory and practice as a critical precedent of enterprise development. This finding builds on current literature which suggest that entrepreneurship careers need in-born "business thinking" (Evans and Jovanovich 1989) and "supportive families" (Gray 2002).

\section{CONCLUSION}

The findings clearly show that the timing of WIL did not have an effect on the employability of agricultural graduates in Zimbabwe. The author acknowledges the benefits of WIL and propounds that if performance is held constant, WIL improves performance character and improves employability. Performance character leverages on job knowledge, hands-on skills and practical orientation and other work-related competencies. Timing of WIL although having an impact on the nature of employability status, it depended on the students' university access and articulation routes. This confirms the assertion by James et al. (2013), that skill acquisition is not a preserve of higher education, it can occur prior, during and parallel to it. As such, it is from the depth and richness of the wider student experiences that employability emerges (Araujo, Wilson and Clarke 2015). The findings are useful in promoting the necessary diversity in WIL curriculum design to facilitate quality and inclusive higher education. This article recommends work-related learning in ensuring synchronous academic and professional value creation and improve quality in higher education and student success as measured by employability and economic status.

The study suggests that if the differences in age are held constant, graduates who undertake WIL throughout the study period have tendencies towards enterprise development postgraduation considering that 21 per cent of such graduates did so whilst none in the other two groups started enterprises of their own. In this regard, this study provides tentative but critical findings that need to be validated through future studies with a possibility of contributing positively to the modernisation and industrialisation of developing economies.

Although agriculture programmes were used for this study, the findings can be extrapolated to any discipline. However, besides to the efficacy of WIL, the absence of 
unemployed graduates in this study need to be treated with caution. This could be attributed to the graduate performance levels considering that all the participants were high performers as measured by the 2.1 grade achievement. There is also a possibility that this could be discipline and industry specific in line with the assertion by Brown, Hesketh and Williams (2003) that graduate employability status is also factor of macro demand and supply.

\section{REFERENCES}

Archambault, L. 2011. The practitioner's perspective on teacher education: Preparing for the K-12 online classroom. Journal of Technology and Teacher Education 19(1): 73-91.

Artess, J., T. Hooley and R. Mellors-Bourne. 2017. Employability: A review of the literature 20122016. York, UK: Higher Education Academy.

Araujo, N., R. Wilson and B. Clarke. 2015. Student engagement for employability: A belonging project case study. In Research and development in higher education: Learning for life and work in a complex world, ed. T. Thomas, E. Levin, P. Dawson, K. Fraser and R. Hadgraft, 38: 1-10. Melbourne, Australia.

Billet, S. 2011. Curriculum and pedagogical bases for effectively integrating practice-based experiences - final report. Strawberry Hills, NSW: Australian Learning and Teaching Council (ALTC)

Blackie, M., M. Mutema and A. Ward. 2009. A study of agricultural graduates in Eastern, Central, and Southern Africa: Demand, quality and job performance issues. Regional Universities Forum for Capacity Building in Africa (RUFORM) and Association for Strengthening Agricultural Research in East and Central Africa (ASERECA) Thrust 4. http://repository.ruforum.org/documents/studyagricultural-graduates-eastern-central-southern-africa-demand-quality-job

Breazeale D., M. Mangheni, J. M. Erbaugh and S. Mbowa. 2004. Making university curricula and training programs responsive to employer needs: The experience of Makerere University's Agribusiness Education Program. Proceedings of the $20^{\text {th }}$ Annual Conference of the Association for International Agricultural Education and Extension (AIAEE), Dublin, Ireland. https://www.aiaee.org/attachments/article/1105/082.pdf

Bridgstock, R. 2009. The graduate attributes we've overlooked: Enhancing graduate employability through career management skills. Higher Education Research \& Development 28(1): 31-44. doi $10.1080 / 07294360802444347$.

Bringle, R. G., J. A. Hatcher and N. Richard. 2010. The role of service-learning on the retention of first-year students to second year. http://hdl.handle.net/2027/spo.3239521.0016.203

Brown, P., A. Hesketh and Williams S. 2003. Employability in a knowledge-driven economy. Journal of Education and Work 16(2): 107-112.

Chaurasiya, K. K., S. K. Babodiya, S. P. S. Somvanshi and C. L. Gaur. 2016. Entrepreneurial behavior of dairy farmers in Gwelior district of Madhya Pradesh. Indian Journal of Dairy Science 69(1): $112-115$.

Chivore, B. R. S. 1994. Teacher effectiveness: A review. Zimbabwe Journal of Educational Research 6(1): 1-30.

Clarke, M. 2017. Rethinking graduate employability: The role of capital, individual attributes and context. Studies in Higher Education: 1-15. doi:10.1080/03075079.2017.1294152.

Comyn, P. and L. Brewer. 2018. Does work-based learning facilitate transitions to decent work? EMPLOYMENT Working Paper No. 246.

Cooper, L., J. Orrell and M. Bowden. 2010. Work integrated learning: A guide to effective practice. Routledge: Abingdon, UK. 
Crebert, G., M. Bates, B. Bell, C. J. Patrick and V. Cragnolini. 2004. Developing generic skills at university, during work placement and in employment: Graduates' perceptions. Higher Education Research \& Development 23(2): 147-165.

D'Abate, C., M. A. Youndt and K. E. Wenzel. 2009. Making the most of an internship: An empirical study of internship satisfaction. Academy of Management Learning and Education 8(4): 527-539.

Dall'Alba, G. 2004. Understanding professional practice: Investigations before and after an educational programme. Studies in Higher Education 29(6): 679-692.

Dickson, K. and M. Kaider. 2012. Designing, developing and delivering work-integrated learning to large student cohorts. In Proceedings of 2012 Australian Collaborative Education Network National Conference, 61-67. Geelong, VIC, Australia: Deakin University.

Divan, A. and S. McBurney. 2016. Understanding how students manage their employability. New Directions in the Teaching of Physical Sciences 11(1): 1-10.

Dressler, S. and A. E. Keeling. 2011. Benefits of cooperative and work-integrated education for students. In International handbook for cooperative and work-integrated education: International perspectives of theory, research and practice, ed. R. K. Coll and K. E. Zegwaard, 261-275. Lowell, MA: World Association for Cooperative Education.

Evans, D., S. and B. Jovanovich. 1989. An estimated model of entrepreneurial choice under liquidity constraints. Journal of Political Economy 97(4): 808-827.

Ferkins, L. 2002. Sporting best practice: An industry view of work placements. Asia-Pacific Journal of Cooperative Education 3(2): 29-34.

Ferns, S., M. Campbell and K. Zegwaard. 2014. Work integrated learning. In Work integrated learning in the curriculum HERDSA Guide, ed. S. Ferns. NSW: Higher Education and Development Society of Australasia Inc.

Fleming, J. and C. Eames. 2005. Student learning in relation to the structure of the cooperative experience. Asia-Pacific Journal of Cooperative Education 6(2): 26-31.

Freudenberg, B., M. Brimble and C. Cameron. 2011. WIL and generic skill development: The development of business students' generic skills through work-integrated learning. Asia-Pacific Journal of Cooperative Education 12(2): 79-93.

Garwe, E. C. and J. Thondhlana. 2019. Higher education systems and institutions, Zimbabwe. In Encyclopaedia of International Higher Education Systems and Institutions, ed. P. Teixeira and J. Shin. Springer, Dordrecht.

Gonyea, R. 2005. Self-reported data in institutional research: Review and recommendations. New Directions for Institutional Research 127: 73-89.

Gray, C. 2002. Entrepreneurship, resistance to change and growth in small firms. Journal of Small Business and Enterprise Development 9(1): 61-72.

Hagel, J., J. S. Brown, R. Mathew, M. Wooll and W. Tsu. 2014. The lifetime learner: A journey through the future of postsecondary education. Deloitte University Press.

Hanna, P., E. Curran, K. Fraser, N. Ayre and P. Nicholl. 2011. Early engagement with employers and employability. In Proceedings of the 11th Annual Conference of the New Zealand Association for Cooperative Education, ed. Hoskyn, 22-26. New Plymouth, New Zealand: NZACE.

Hills, J. M., G. Robertson, R. Walker, M. A. Adey and I. Nixon. 2003. Bridging the gap between degree programme curricula and employability through implementation of work-related learning. Teaching in Higher Education 8(2): 211-231.

Hoang, V. V. 2018. Enhancing graduate employability at Vietnam National University, Hanoi: A case study. Vietnam National University. Hanoi, Vietnam

Hoeckel, K. 2014. Youth labour markets in the early twenty-first century. In Understanding employer engagement in education: Theories and evidence, ed. A. Mann, J. Stanley and L. Archer, 66-76. Abingdon, Oxon: Routledge.

Jackson, D. 2013. Employability skill development in work-integrated learning: Barriers and best 
practice. Studies in Higher Education. doi: 10.1080/03075079. 2013.842221.

Jackson, D. 2016. Developing pre-professional identity in undergraduates through work-integrated learning. Higher Education: 1-21.

James, S., C. Warhurst, G. Tholen and J. Commander. 2013. What we know and what we need to know about graduate skills. Work Employment and Society 27(6): 952-963.

Kinash, S., L. Crane, M. M. Judd and C. Knight. 2016. Discrepant stakeholders' perspectives on graduate employability strategies. Higher Education Research \& Development 35: 951-967. Doi: 10.1080/07294360.2016.1139555.

Kyndt, E. and H. Baert. 2013. Antecedents of employees' involvement in work-related learning: A systematic review. Review of Educational Research 83: 273-313. doi: $10.3102 / 0034654313478021$

Leong, S. 2004. How to develop talent for training. New York: Management Books.

Maher, A. 2004. Oven-ready and self-basting? Taking stock of employability skills. Link 1. Higher Education Academy Network for Hospitality, Leisure, Sport and Tourism: 7-9.

Martin, A. J. and H. Hughes. 2009. How to make the most of work integrated learning. Palmerston North, New Zealand: Massey University.

McKinnon, S. 2013. A mismatch of expectations? An exploration of international students' perceptions of employability skills and work-related learning. In Cross-cultural teaching and learning for home and international students, ed. J. Ryan, 211-224. Routledge: Abingdon, Oxfordshire, UK.

McKune, T. 2013. The academic benefit of experiential learning for Civil Engineering students on the Pietermaritzburg campus of the Durban University of Technology. Proceedings of the Biennial Conference of the South African Society for Engineering Education, Cape Town. 11-12 June, 2013.

Morley, L. 2002. Producing new workers: Quality, equality and employability in higher education. Quality in Higher Education 7(2): 131-138. https://doi.org/10.1080/13538320120060024

Mounce, P. H, D. S. Mauldin and R. L. Braun. 2004. The importance of relevant practical experience among accounting faculty: An empirical analysis of student' perceptions. Issues in Accounting Education 4.

Muchemwa, S. 2018. Programme improvement: Analysis of internship assessment of the Bachelors of Languages and Communication Degree at one university in Zimbabwe. International Journal of Social Sciences and Educational Studies 4(4): 64-79.

National University of Science and Technology. 2003. Yearbook 2005. Bulawayo, Zimbabwe.

Nguyen, N. T. 2019. Cultural modalities of Vietnamese higher education. In Education in the AsiaPacific Region: Issues, Concerns and Prospects, ed. N. Nguyen and L. Tran. Reforming Vietnamese Higher Education. 50. Springer, Singapore

NUST see National University of Science and Technology.

Okafor, T. 2015. Positioning employability as a core objective in quality assurance. ICQAHEA ABUJA. https://slideplayer.com/slide/9480875/

Ouraich, I., J. Lowenberg-DeBoer, A. Soumah and D. Diallo. 2017. Employment prospects for agricultural graduates in Guinea Conakry. Journal of Agricultural Extension and Rural Development 9(1): 5-13. doi: 10.5897/JAERD2016.0804

Park, D., E. Tsukayama, G. P. Goodwin, S. Patrick and A. L. Duckworth. 2016. A tripartite taxonomy of character: Evidence for intrapersonal, interpersonal, and intellectual competencies in children. Contemporary Educational Psychology 48: 16-27. doi: 10.1016/j.cedpsych.2016.08.001.

Peach, D. and N. Gamble. 2011. Scoping work-integrated learning purpose, practices and issues. In Developing learning professionals, ed. S. Billet and A. Henderson, 7: 169-186. Dordrecht, Netherlands: Springer.

Phuthi, N. 2012. Enhancing quality academic practice through integrated industry-based learning, Doctor of Philosophy in Assessment and Quality Assurance in Education and Training. 
University of Pretoria, South Africa.

Prince, H. 2005. Graduate pathways: A longitudinal study of graduates in outdoor studies in the U.K. Journal of Adventure Education and Outdoor Learning 5(1): 21-33. http://insight. cumbria.ac.uk/id/eprint/564/

Rambe, P. 2018. Using work integrated learning programmes as a strategy to broaden academic and workplace competencies. SA Journal of Human Resource Management 16(0): 1-16. https://doi.org/ 10.4102/sajhrm.v16i0.999

Rampersad, G. and V. Zivotic-Kukolj. 2018. Work-integrated learning in science, technology, engineering and mathematics: Drivers of innovation for students. International Journal of WorkIntegrated Learning 19(2): 193-204.

Rodzalan, S. A. and M. M. Saat. 2012. The effects of industrial training on students' generic skills development. Procedia - Social and Behavioral Sciences, 1-12

Roopnarain, S. and B. Akoobhai. 2014. Workplace based experience (WBE) - preparing the student for the world of work. The African Journal for Work-Based Learning 2(2): 41-50.

Salkind, N. J. 2012. Exploring research. $8^{\text {th }}$ Edition. Upper Saddle River, NJ: Pearson Education, Inc.

Schultz, T. 1961. Investment in human capital. The American Economic Review 51(1): 1-17.

Seider, S., J. Gilbert, S. Novick and J. Gomez. 2013. The role of moral and performance character strengths in predicting achievement and conduct among urban middle school students. Teachers College Record 115(8): 1-18.

Shah, A., K. Pell and P. Brooke. 2004. Beyond first destinations: Graduate employability survey. Active Learning in Higher Education 5(1): 9-26.

Sin, S., A. Reid and A. Jones. 2012. An exploration of students' conceptions of accounting work. Accounting Education 21(4): 323-340.

Smith, C., S. Ferns and L. Russell. 2014. Conceptualising and measuring "employability": Lessons from a National OLT Project. ACEN National Conference: 1-10. Gold Coast: Australian Collaborative Education Network Limited.

Støren, L. A. and P. O. Aamodt. 2010. The quality of higher education and employability of graduates. Quality in Higher Education 16(3): 297-313. http://dx.doi.org/10.1080/13538322.2010.506726

Suleman, F. 2018. The employability skills of higher education graduates: Insights into conceptual frameworks and methodological options. Higher Education 76(2): 263-278. https://doi.org/10.1007/s10734-017-0207-0

Trede, F. 2012. Role of work-integrated learning in developing professionalism and professional identity. Asia Pacific Journal of Human Resources 13(3): 159-167.

Valadkhani, A., A. C. Worthington and M. Houlbrook. 2001. Work-based learning as critical social pedagogy. Australian Journal of Adult Learning 41(3): 313-334.

Webb, R. M. and J. Hayes. 2008. Work integrated learning: Will it work for Spatial Science Wilers? In Proceedings Queensland Spatial Conference 2008: Global warning: What's happening in paradise?, ed. K. McDougall, 0015:1-0015:7. Gold Coast, Qld, Australia.

Weddle, P. 2010. Why employers don't hire perfectly qualified people. http://asq.org/career/ resources/articles/hiring-perfectly-qualified-people.html

Wessels, M. 2014. Cooperative education at the Tshwane University of Technology: A new direction for work-integrated learning and employability. The African Journal for Work-Based Learning 2(2): $1-15$.

Wilton, N. 2012. The impact of work placements on skills development and career outcomes for business and management graduates. Studies in Higher Education 37(5): 603-620. doi: $10.1080 / 03075079.2010 .532548$.

Wolff, R. and M. Booth. 2018. Bridging the gap: Creating a new approach for assuring 21 st century employability skills. Change: The Magazine of Higher Learning 49(6): 51-54. https://doi.org/10.1080/00091383.2017.1399040 
Wright, N., R. Davis and S. Bucolo. 2013. The creative citizen: Understanding the value of design education programs in the knowledge economy. In Proceedings of the 2nd International Conference for Design Education Researchers 4(4): 2230-2248. ABM-media.

Zegwaard, K. E. and S. McCurdy. 2014. The influence of work-integrated learning on motivation to undertake graduate studies. Asia-Pacific Journal of Cooperative Education 15(1): 13-28. 